\title{
THE INFLUENCE OF JIGSAW TECHNIQUE AND SPEAKING ANXIETY TOWARD STUDENT'S SPEAKING COMPETENCE
}

\author{
Desi Surlitasari Dewi, Aulia Putri \\ Universitas Riau Kepulauan, Jl. Batuaji Baru 99, Batam, Indonesia \\ e-mail: belldaisy46@gmail.com
}

\begin{abstract}
Lately, innovative models to teach English have been widely discussed. Communicative competence is definitely the goal when we teach speaking to foreign language learners. However, the goal was rarely achieved in speaking class. In this study, one of technique in Cooperative Learning, jigsaw technique, was proposed. It was predicted that jigsaw technique of teaching speaking and student's speaking anxiety had effect toward student's speaking competence. Jigsaw is a technique that can be used in speaking class as it assigns the students to work in team, where they tend to feel secured and comfortable to learn speaking. While speaking anxiety could be a language barrier distracting the students to succeed in speaking class. It is an internal factor from the student's mind which prevents them from delivering communicative competence. Thus, the objectives of the study were to find out the effectiveness of jigsaw technique in teaching speaking as well as the influence of speaking anxiety, one of psychological factors in learning foreign language, towards the student's speaking competence. The population of the research was the first semester students of English Department Universitas Riau Kepulauan. The research method was a quasi experiment and the data were taken by using a speaking test and questionnaires. Students' speaking competences were assessed based on six categories namely fluency, task, comprehension, grammar, pronunciation, and vocabulary. While Saito's speaking anxiety questionnaire was used to reveal student's speaking anxiety. Then, the data were analyzed by using Anova.
\end{abstract}

Keywords: jigsaw technique, speaking anxiety, speaking competence

Abstrak

Akhir-akhir ini, model inovatif untuk mengajar bahasa Inggris telah secara luas Dibahas. kompetensi komunikatif jelas tujuan ketika kita mengajar berbicara untuk pelajar bahasa asing. Namun, gol itu jarang Dicapai dalam kelas berbicara. Dalam penelitian ini, salah satu teknik dalam Cooperative Learning, teknik jigsaw, diusulkan. Diperkirakan bahwa teknik jigsaw pengajaran berbicara dan kecemasan berbicara siswa memiliki efek terhadap kemampuan berbicara siswa. Jigsaw adalah teknik yang dapat digunakan dalam kelas berbicara seperti itu menugaskan siswa untuk bekerja dalam tim, di mana mereka cenderung kisaran merasa aman dan nyaman untuk belajar berbicara. Sementara berbicara kecemasan bisa menjadi hambatan bahasa mengganggu siswa untuk berhasil dalam berbicara kelas. Ini adalah faktor internal dari pikiran siswa yang yang mencegah mereka dari memberikan kompetensi komunikatif. Tus, tujuan dari penelitian ini adalah untuk mengetahui efektivitas teknik jigsaw dalam mengajar berbicara serta pengaruh berbicara kecemasan, salah satu faktor psikologis dalam belajar bahasa asing, terhadap kompetensi berbicara siswa. Populasi dari penelitian ini adalah semester pertama mahasiswa Jurusan Bahasa Inggris, Universitas Kepulauan Riau. Metode penelitian adalah kuasi eksperimen dan data diambil dengan menggunakan tes berbicara dan kuesioner. kompetensi berbicara siswa dinilai berdasarkan enam kategori yaitu kelancaran, tugas, pemahaman, tata bahasa, pengucapan, dan kosa kata. Sementara berbicara kecemasan kuesioner Saito digunakan untuk mengungkapkan kecemasan berbicara siswa. Kemudian, data dianalisis dengan menggunakan ANOVA.

Kata kunci: teknik jigsaw, berbicara kecemasan, kemampuan berbicara 


\section{INTRODUCTION}

Speaking fluency is one of the problems mostly faced by the students. It is caused by some factors such as techniques or methods in teaching, which focuses on the grammatical accuracy instead of speaking fluency. Several years ago, Grammar Translation Method was frequently used in foreign language classroom. Students were required to acquire foreign language by translating foreign language into the target language, so it results on poor speaking fluency. Nowadays, the shift on the purpose of foreign language learning takes us into the importance of communicative competence. However, to achieve communicative competence needs some adjustment in foreign language classroom and there are things needs to be considered.

Teachers need to make effort on some things such as using innovative strategies or different methods to stimulate the students to use the language actively. Some strategies that can be used for speaking are role play, simulation, demonstration, jigsaw, and total physical response. In this study, jigsaw is applied in foreign language classroom to see whether it is effective for student's speaking skill. Jigsaw is a technique in which the students are divided into some groups and each group is given a task which is different with the other group. Hopefully, applying this technique in speaking classroom can lead to the student's success in speaking.

However, teaching technique is not the only influencing factor in student's success or failure. Psychological factor, which derives from the learner's own mind, needs to take into consideration in planning a foreign language classroom activities. It could be possible as learning foreign language is an emotional experience and the success can be determined by the learner's mind. Psychological factor could be a factor that determine whether the students need to do something for their success.

Motivation and self confidence has been researched thoroughly since decades for its involvement with the success of learning foreign language. The other psychological factor is foreign language speaking anxiety. It is an overwhelming feeling of worry and tension manifested in physical symptomps such as sweaty, rapid heartbeat, and speak unclearly as a result of the doubt of their ability in speaking and threat that possibly arises.

\section{METHODOLOGY}


This research was a quasi experimental study and conducted at English Department Universitas Riau Kepulauan. The data were in the form of quantitative data and they were taken from a test. They are the scores of students' speaking after having eight times treatment for each class. The researcher analyzed the data using ANOVA or analysis of variance and Tukey test.

The data were analyzed by using multifactor analysis of variance $2 \times 2 \mathrm{H}_{\mathrm{o}}$ is rejected if $F_{o}$ is higher than $F_{t}\left(F_{o}>F_{t}\right)$, it means that there is a significant difference. After knowing that $\mathrm{H}_{\mathrm{o}}$ was rejected, the analysis was also continued to know the difference between the two groups and cells by using Tukey test. To know which group was better, the mean scores of the groups and cells are compared.

After knowing the result of computation of ANOVA factorial design, it needed Tukey HSD Test to compare the means of every treatment with the other means.

\section{RESULT}

\section{Result of Study}

The data were analyzed by using ANOVA 2 x 2 . The results are described below.

Table 1 The mean scores

\begin{tabular}{|c|c|c|c|}
\hline & $\mathrm{A}_{1}$ & $\mathrm{~A}_{2}$ & \\
\hline $\mathrm{B}_{1}$ & 77,47 & 60,40 & 68.93 \\
\hline $\mathrm{B}_{2}$ & 63,33 & 68,00 & 65,67 \\
\hline & 70,40 & 64,20 & \\
\hline
\end{tabular}

Table 2 Summary of a $2 \times 2$ Multifactor Analysis of Variance

\begin{tabular}{|l|l|l|l|l|l|l|}
\hline Source of variance & SS & df & MS & $\mathbf{F}_{\mathbf{0}}$ & $\mathbf{F}_{\mathbf{t}(\mathbf{. 0 5})}$ & Meaning \\
\hline Between columns (stress) & 576,6 & 1 & 576,6 & 16,65 & 4,016 & Significant \\
\hline Between rows (task) & 160,07 & 1 & 160,07 & 4,62 & 4,016 & Significant \\
\hline
\end{tabular}


(1) $F_{o}$ between columns $(16,65)$ is higher than $\mathrm{Ft}(4,016)$ at the level of significance $\alpha=0,05$, it can be concluded that jigsaw technique is more effective than role play to teach speaking;

(2) $F_{o}$ between rows $(4,62)$ is higher than $F_{t}(4,016)$ at the level of significance $\alpha=$ 0,05 , so the difference between rows is significant. It can be concluded the students having lower speaking anxiety have better speaking skill from those having higher speaking anxiety

\section{Discussion of Study}

This research is done as efforts to find some innovations in teaching speaking. One of them is using jigsaw in teaching speaking as it has been discussed in the previous discussion. The following are the discussions of the research findings.

\section{a. Jigsaw is more effective than role play to teach speaking}

Jigsaw is a technique of teaching speaking in which the students work together in a group. Each group is given a different task. It is an interesting technique in which the students are guided by an experienced teacher. Each student involves in two groups, kelompok asal and kelompok ahli. They could practice their speaking skill to understand and deliver the information given by their peers as a result of discussion in kelompok asal. In this activity, they could practice and improbve their basic ability to speak which could be measured by speaking indicators explained by Brown namely, comprehension, vocabulary, pronunciation, fluency, and structure.

The other technique to teach speaking is role play. It is less challenging compared to jigsaw as the students are demanded to speak based on their role in a previously given topic. The dialog has been prepared before performed so it is possible for the students to memorize the dialog. It results to the lack of proficiency in comprehension, fluency, vocabulary, and structure.

Based on above explanation, it can be concluded that jigsaw is more effective than role play to teach speaking. 
b. Students who have lower anxiety has better speaking competences than students who have higher anxiety.

Speaking anxiety is a feeling of worry that the students cannot achieve to speak. Speaking anxiety can be an affective filter that prevents the students to absorb the language input. It can make the students feel worry during the process of learning so they are under pressured to complete their tasks. It can influence their performance in speaking. The students who have higher speaking anxiety are usually afraid of making mistakes in speaking class and they hesitate to speak without considering the threat. They also face difficulties in speaking classroom as they are not confidence in completing their tasks. Sometimes, they are not confidence enough to produce language.

From the explanation above, it can be concluded that foreign language speaking anxiety definitely affects student's speaking skill.

c. There is an interaction between student's speaking anxiety and teaching technique

Foreign language speaking anxiety contributes to the effectiveness of teaching techniques in the class. The teacher must know which technique is more suitable in the class considering the students' speaking anxiety.

This method is more suitable for the students having high anxiety because the teacher asked the students to work in group in which it can reduce the student's speaking anxiety when they speak individually in a given task.

Then, it is concluded that there is an interaction between student's speaking anxiety and teaching technique.

\section{CONCLUSION AND SUGGESTION}

\section{Conclusion}

Based on the finding, it can be concluded that in general jigsaw technique is more effective than role play in teaching speaking. There is also an interaction between teaching techniques and students' speaking anxiety in teaching speaking. For the students who have low speaking anxiety, jigsaw technique is more effective than role play, but for the students who have high speaking competence anxiety, role play 
is more effective than jigsaw technique to teach speaking competence. It means that the effectiveness of the methods for teaching speaking depends on the levels of students' speaking anxiety.

\section{Suggestion}

a. In general, teacher can use jigsaw technique to teach speaking as one of the alternatives of teaching speaking

b. Teacher has to consider that speaking anxiety can influence the students' speaking skill in foreign language classroom.

c. For the students who have higher speaking anxiety, they should encourage themselves and be aware that they have to be more active in their involvement in the teaching and learning process and they do not need to fully aware that they are being assessed and watched in completing speaking task to reduce their speaking anxiety.

d. Other researchers can use this result of the study as the starting point to continue the next result.

e. The researchers can create better study based on the weaknesses that they know about this study.

\section{References}

Allen, S.J. 1998. Social Phobia Anxiety Inventory for Children.In the $15^{\text {th }}$ Mental Measurement Yearbook. Retrieved: January 26 ${ }^{\text {th }}$, 2012. From Whitelib.emporia.edu.psych

Aronson, E, Stephen. 1987. The Jigsaw Classroom. Beverly Hills, CA: Sage Publications. Retrieved on February 18, 2010 at http://www.Jigsaw.org

Bandura, A. 1997. Self-efficacy: The exercise of control. New York: W. H. Freeman

Brown, H. Douglas. 2004. Language Assessment: Principles and Classroom Practices. New York: Longman.

Brown, H. Douglas. 2000. Teaching by Principles: An Interactive Approach to Language Pedagogy (Second Language Edition). New York: Longman.

Chaney, A.L., and T.L. Burk. 1998. Teaching Oral Communication in Grades K-8. Boston: Allyn\&Bacon.

Chaudhary, Shreesh. 2008. "Testing Spoken English for Credit within the Indian University System." Teaching English as Second or Foreign Langauge 12 (3). 
Hakkarainen, Kay. 1994. Jigsaw. Retrieved February 19, 2010 athttp://mlab.uiah.fi/polut/ Yhteisoiiin/tyokaluJigsaw.html

Harmer, Jeremy. 1998. How to Teach English . Pearson Education Ltd.

Hartmann, R.R.K., \& Stork, F. C. 1976. Dictionary of Language and Linguistics. New York: Wiley.

Horwitz, Elaine K., Horwitz., Michael B., and Cope, Joann. 1986. The Modern Language Journal. Foreign Language Classroom Anxiety.. Vol. 70, No.2. Blackwell Publishing.

Kagan, Spencer. 1992. Cooperative Learning. Resources for teachers, in. Retrieved on March 2009 at http://mlab.uiah.fi/polut/yhteisollinen/tyokalu.Jigsaw.html

Matheson. 1998. Jigsaw Reading. The Internet TESL No. 3 May 1998. Retrieved on February 19, 2010 at http://www.asian-efl-journal.com

O’Malley, J. Michael and Lorraine Valdez Pierce. 1996. Authentic Assessment for English Language Learners. Virginia: Addison-Wesley Publishing Company.

Occhipinti, Alessia. 2009. Foreign Language Anxiety in in-Class Speaking Activities : Two Learning Contexts in Comparison. Oslo: Unpublished Thesis

Saito, Yoshiko. 1999. The Modern Language Journal.Foreign Language Anxiety.Volume 83, Issue 2. Retrieved from http://www.onlinelibrary.wiley.com

Spielberger, Charles D. 1976. Cross Cultural Anxiety. Wiley \& Sons, Incorporated, John.

Richards, Jack C, and Willy A Renandya. 2002. Methodology in Language Teaching : An Antholohgy of Current Practice. Cambridge University Press.

Ur, Penny. 1991. A Course in Language Teaching : Practice and Theory. Series editor : Marion Williams and Tony Wright. Cambridge University Press. 